\title{
Eros en seksuele natuur
}

\author{
M.F. Heyns \\ Departement Filosofie \\ Potchefstroomse Universiteit vir CHO \\ POTCHEFSTROOM
}

\begin{abstract}
The aim of this article is to expose a dichotomy between the inter-and intrapersonal aspects of sexuality that haunt the current discourse on sexual normality. This division has led to a dual movement: in one direction to a moral relativism and in the other to an exclusive focus on sexual instincts. Thus, in the current discourse on sexuality, the interpersonal dimension of sexuality is underplayed, while the intrapersonal dimension is overemphasized. I argue instead for a bridging of the gap between the inter-and intrapersonal dimensions of sexuality. The reason: neither moral relativism nor a rigid deterministic structure for sexual instincts represents an adequate view of, on the one hand the description of sexuality, and on the other the prescription of the expression of that sexuality. In conclusion, I point to a few consequenses of the integration of both dimensions for sexual normality.
\end{abstract}

\section{Inleiding}

'n Debat is gedurende die laat sestigerjare tot tagtigerjare in wysgerige kringe in die Verenigde State van Amerika gevoer oor die konsepte wat gebruik word om seksualiteit te beskryf. 'n Fokuspunt in dié debat is die konsep perversiteit. Die aanname van dié debat is dat die tipering van sekere seksuele praktyke as pervers, konseptueel geanaliseer moet word sodat die geldigheid al dan nie van die begrip vasgestel kan word. Daar is verwag dat baie omtrent seksualiteit as sodanig geleer kan word uit 'n bespreking van die konsep perversiteit (Nagel, 1980: 76). Die motief strek dus dieper as 'n blote konsepanalise van die woord perversiteit. Die onderliggende vraag is of daar enige beginsels is waarvolgens seksuele normaliteit bepaal kan word.

Die algemene patroon van hierdie debat is deur Humber (1988:331-337) soos volg geanaliseer: Deelnemers aan die debat stel hul siening van die seksuele funksie in die mens se lewe as uitgangspunt. Hierdie beskrywing van die seksuele funksie word geregverdig deur 'n beroep op die 'feite' omtrent die menslike natuur. Perverse gedrag is seksuele handelinge wat nie hierdie essensiěle funksie 
van seksualiteit vervul nie. Op grond van hierdie aannames skryf Humber (1988: 346 ) voor dat as ' $n$ teoretiese definisie vir normale seksualiteit ontwikkel wil word, moet

* die noue verband tussen die algemene antropologie en die konsep van normale seks erken word, en moet

* 'n mensbeeld ontwikkel word wat soveel moontlik aspekte omtrent menswees omvat.

Humber is op grond van hierdie vereistes daarvan oortuig dat nie een van die definisies vir seksuele normaliteit bevredig nie aangesien die meeste definisies nie deur ' $n$ mensbeeld gelegitimeer word nie. Hy grond sy oortuigings op die volgende:

* Aannames rondom die mensbeeld word nie uitgespel nie, en

* die aannames oor die menslike natuur wat gemaak word, is lank nog nie algemeen aanvaarde 'feite' nie.

Ek sal veral die eerste kritiekpunt ' $n$ tree verder neem. My hipotese is dat die huidige mensbeelde agter definisies vir normale seksualiteit nie alleen mank gaan aan ' $n$ onuitgesproke en onberedeneerde formulering nie, maar dat dit veral gekniehalter word deur ' $n$ innerlike spanning; ' $n$ mensbeskoulike dichotomie tussen die sogenaamde seksuele natuur van die mens en die erotiese funksies van seksualiteit.

\section{Teoretiese vertrekpunte}

Ter wille van ' $n$ volledige verstaan van die uiteensetting van bogenoemde hipotese moet eers kennis geneem word van die volgende teoretiese uitgangspunte

\subsection{Antropologiese aannames}

Die mens is ' $n$ eenheidswese in wie tog wel ' $n$ verskeidenheid dimensies en funksies onderskei kan word. Hierdie verskeidenheid vorm 'n onderlinge samehang, dit wil sê die afsonderlike dimensies en funksies is telkens 'n uiting van die volledige mens. Dit beteken dat die samestellende lede van die verskeidenheid nie onafhanklik van mekaar kan funksioneer of selfs in botsing met mekaar gesien kan word nie. Geen dimensie of funksie van die mens kan ook belangriker as die ander gesien word nie. Sodanige beklemtoning van een dimensie of funksie sou onmiddellik ' $n$ grens teenoor die ander dimensies en funksies opstel wat gemaklik tot ' $n$ isolering van die beklemtoonde dimensie kan lei. Hierdie isolering kan op sy beurt oorgaan in ' $n$ verabsolutering van die dimensie en sou ook geïnterpreteer 
kon word asof die hele mens vir sy menswees van hierdie enkele aspek afhanklik is. Die mens is van God afhanklik vir sy ontstaan, voortbestaan en die rigting van sy lewe. Indien 'n enkele dimensie van menswees belangriker as die ander geag word, is die versoeking groot om daardie dimensie as die gewer van oorsprong, voortbestaan en rigting te sien. Vir die behandeling van die seksuele dimensie van menswees is hierdie algemene uitgangspunt belangrik want die argument sal juis daarop ingestel wees dat fyner onderskeidings ten opsigte van die seksuele dimensie gemaak kan word. Hierdie fyner onderskeidings moet egter in samehang met die totale mens funksioneer en moet in samehang met mekaar gesien word.

Die tweede algemene uitgangspunt geld spesifiek vir twee dimensies van menswees. Die Kanadese filosoof Charles Taylor (1989:25-32) noem twee ineengevlegte voorwaardes vir menslike lewe:

* Die eerste voorwaarde is die feit dat die mens morele beslissings binne betekenisvolle kontekste of raamwerke neem. Raamwerke as sodanig word deur die mens benodig sodat hy homself in die werklikheid kan oriënteer; hiervolgens word bepaal wat belangrik is en wat gedoen behoort te word. So 'n raamwerk veronderstel ook dat sekere ideale hoër geag sal word as ander - Taylor praat van 'sterk evaluering' of 'kwalitatiewe onderskeidings'. Hierdie kwalitatiewe onderskeidings word gemanifesteer in die verskillende agtergrondsvooronderstellings of ideale vir ons morele reaksies wat betekenis aan hierdie reaksies gee. Taylor beskryf die bestaan van raamwerke as ' $n$ ontologiese ruimte waarin sekere basiese en onontkombare vrae aan die mens gevra word. Die antwoorde, oftewel die inhoud van die morele spasie, neig egter om subjektief te wees.

* Die tweede voorwaarde vir lewe is die feit dat 'n mens homself binne ' $n$ onontkombare sosiale wisselwerking met ander mense bevind. Binne hierdie wisselwerking word die ideale vir oriëntasie in die wêreld gevorm. Om dus jou weg in hierdie wêreld te vind (keuses te kan mak en op te tree), moet die afhanklikheid van sosiale relasies erken word.

\section{2 'n Basiese onderskeiding ten opsigte van seksualiteit}

Wanneer laasgenoemde voorwaarde vir die menslike bestaan ondersoek word, kom die volgende na vore: Volgens Taylor (1991:32-35, 43-53) word die horisonne van betekenis wat aan die individu oriëntering verskaf (aan hom ' $n$ identiteit gee), aan die mens deurgegee in die fundamenteel dialogiese verhouding tot die medemens. Dit beteken dat die vorming van 'n eie identiteit vir die moderne mens nie binne instrumentele intieme en sosiale relasies kan geskied nie. Inteendeel, instrumentele verhoudings (sosiale atomisme) sal die vorming van 'n persoonlike identiteit inhibeer en selfs ondergrawe. 
Een van die belangrike moderne ideale (met ' $n$ klem op die dialogiese aard van menswees) is die Christelike voorrang aan die gewone lewe. Taylor (1985:37) skryf dit toe aan die invloed van die sestiende-eeuse Reformasie op die vorming van die oriënteringsraamwerk van die moderne tyd. Hierdie beklemtoning van die gewone lewe lei daartoe dat ' $n$ hoë premie geplaas word op menslike aktiwiteite soos gesinslewe en die waarde van die gewone mens se daaglikse arbeid ("the life of production and reproduction"). Die impak van hierdie ideaal op spesifiek moderne seksualiteit is volgens Taylor (1991:45) dat

... this culture puts a great emphasis on relationships in the intimate sphere, especially love relationships. These are seen to be the prime loci of selfexploration and self-discovery and among the most important forms of selffulfilment.

Met hierdie uitspraak is implisiet al gedui op 'n belangrike ideaal binne die seksuele dimensie van menswees, naamlik die belangrikheid van intermenslike (of inter-individuele) relasies binne moderne seksuele praktyke. In hierdie opsig kan gepraat word van die erotiese aard van seks. Hierdie Platoniese gebruik van eros dui op die geslagtelike begeerte se funksie om mense te bind of na mekaar aan te trek ${ }^{1}$. Aan die ander kant bestaan ook die seksuele aanleg van die individu in dinge soos die mens se aangebore liggaamlik geslagtelike identiteit en bepaalde biologiese en emosionele seksuele drange. Hierdie sake kan beskryf word as die intramenslike (of intra-individuele) dimensie van seksualiteit.

Hierdie onderskeiding word bevestig deur die Franse filosoof Michel Foucault (1979:106-107) se identifisering van twee magstrategieë wat histories aangewend is om seksualiteit te rig. Die eerste dominante strategie is die ontplooiing van alliansie (my onderskeiding van die intermenslike dimensie van seksualiteit). Hiervolgens mag seksrelasies net binne die huwelik toegelaat word en gaan dit om die band tussen mense en om juridiese statute wat onder andere deur die kerk gebruik is om seksuele verhoudinge te reël. Die tweede strategie is die ontplooiing van seksualiteit (my onderskeiding van die intramenslike dimensie van seksualiteit). Tans is die ontplooiing van seksualiteit die dominante magstrategie waarvolgens

1 Ter wille van 'n positiewe konnotasie beskryf Plato eros as die bindingskrag tussen tecnoorgesteldes: byvoorbeeld tussen skynbaar onversoenbare elemente soos kouc en hitte, bitterheid en soetheid, droogheid en nattigheid - Plato (Symposium 186-188). Dit is ook die krag agter die begeerte van die twee geslagte na mekaar. Die verduideliking hiervoor word gevind in die mite van die androgiene geslag wat sou bestaan het uit sowel manlike as vroulike eienskappe maar wat as gevolg van sy rebellic teen die gode in twce verdcel is Hierna was daar altyd die begeerte terug na die ander helfte van die geslag; dit is 'n begeerte om iets in die ander in besit te neem: iets wat nie besknf kan word nie maar wat meer is as blote sinlike plesier; die cen siel dors na dic ander - Plato (Symposium 189194). 
seksualiteit beheer word. Hiervolgens word die sensasies van die liggaam, die kwaliteit van plesier en die aard van ervaringe deur verskillende psigo-analitiese tegnieke beheer en nagespeur. Volgens Foucault (1979:37-41) het daar dus 'n verskuiwing in die beheer van seksualiteit plaasgevind: die beheptheid met die sosiale beheer ten gunste van heteroseksuele monogamie vervaag en die egpaar verdwyn as objek van sosiale beheer. In die plek daarvan kom die seksualiteit van perverte onder die soeklig. Die 'oortreding teen die natuur' word 'n terrein geskei van die sfeer van moraliteit. In laasgenoemde gaan dit om die immanente wette van seksualiteit wat skerp onderskei moet word van die wette van die huwelikstaat. Die speerpunt van my kritiek ${ }^{2}$ sal nie soseer teen die maak van 'n onderskeid tussen die twee dimensies van seksualiteit wees nie, maar die geneigdheid om die twee dimensies ook in die lewenspraktyk van mekaar te skei en een dimensie ten koste van ' $n$ ander te beklemtoon.

\subsection{Die verskuiwing in die diskoers oor seksualiteit}

\subsubsection{Die relativering van die intermenslike dimensie van seksualiteit}

Die moderne verskuiwing weg van die klem op die interpersoonlike dimensie van seksualiteit kan verduidelik word as die gevolg van 'n verworde vorm van ' $n$ belangrike ideaal binne die moderne oriënteringsraamwerk. Taylor (1991:25-29) noem dit die ideaal van outensiteit en wys daarop dat hierdie ideaal wortel in die idee dat ' $n$ mens deur ' $n$ innerlike stem aangespreek word. In sy finale moderne beslag (die ideaal het ' $n$ lang geskiedenis wat minstens al by Augustinus ' $n$ aanvang neem), beteken dit dat die innerlike stem aan elke individu vertel hoe hy op 'n unieke wyse mens kan wees. Taylor (1991:27-28, 55-56) prys hierdie ideaal aan maar spreek hom uit teen 'n verloopte vorm daarvan soos gemanifesteer in die ideaal van radikale selfdeterminerende vryheid. Laasgenoemde ideaal lê eensydig klem op menslike outonomie en skeppingspotensiaal. Hierdie eensydigheid ontwikkel twee onaanvaarbare trekke: sosiale atomisme waarvolgens menslike verhoudings bloot instrumenteel gesien word, en radikale antroposentrisme waarvolgens die voorwaardes vir selfverwesenliking deur die self voortgebring

2 Volgens Foucault (1979:60 en 154-156) se analise is die moderne veronderstelling dat daar 'n waarheid, 'scks', in dic diepste natuur van dic mens skuil wat gedwing moct word om na dic oppervlak te kom. Die vroeëre veragting van scksualiteit het plek gemaak vir die bestaan van 'scks' as die verborge dryfkrag of genereerder van sin wat aan die mens sy identiteit besorg. Hierdie analise gee aanleiding tot Foucault (1977:26-30) se poging om mag te ontmasker: dic socke na dic siel van dic mens is niks anders as ' $n$ bedekte poging om mag or die lewe uit te oefen nie: dic liggaam moct onderwerp word deur middel van ' $n$ 'tegnologie van die liggaam'. In hicrdic artikel is die fokus nic soseer op die onderwerping van dic mens deur mag nie maar op dic onhoudbaarheid van die skeiding van die twee dimensies van seksualiteit 
word sodat aansprake wat van buite die mens kom, byvoorbeeld die stem van God, genegeer kan word (Taylor, 1991:57-58).

Dit is duidelik dat 'n sosiale atomisme 'n sterk dryfveer in die rigting van 'n eksklusiewe fokus op die intramenslike dimensie van seksualiteit is. Minder ooglopend maar net so belangrik is die radikale antroposentrisme se invloed. Antroposentrisme (subjektiwisme) veroorsaak 'n relatiwisme wat die bo-subjektiewe horison van betekenis ontken - 'n betekenishorison waarvolgens kwalitatiewe onderskeidings gemaak word. Kwalitatiewe onderskeidings en besluite word in die finale instansie arbitrêr deur die mens geneem: die klem word gelê op die reg om keuses te maak - Taylor praat van 'n "affirmation of choice itself". Hierdie reg veroorsaak dat die betekenis van die keuse wat gemaak word, versluier word (Taylor, 1991: 36-38, 68-69).

Dit is volgens Taylor (1991:37-38) die geval in die diskoers waarin alternatiewe seksuele oriënterings of relasies soos homoseksualiteit gelegitimeer word. Voorstanders van homoseksualteit se sterk argument is dat mense toegelaat moet word om hul seksuele oriëntasie te kies. So byvoorbeeld meen Margolis (1975:294296 \& 300) dat homoseksualisme nie beskou kan word as óf 'n sosiale siekte óf kriminele gedrag nie. Volgens hom is die enigste alternatiewe negatiewe evaluering dié van perversiteit. Perversiteit suggereer dat sekere tipes seksuele gedrag natuurlike en normale funksies of relasies ignoreer of oorskry. Vir Margolis is dit egter oënskynlik onmoontlik om sodanige universele normale funksies en relasies te ontdek. Aangesien seksuele norme en gebruike volledig kultuur- en gemeenskaprelatief is, moet dit eerder as ' $n$ private aangeleentheid beskou word. Hierdie argument word gevoer op sterkte van 'n onderliggende neiging in die ideaal van outensiteit, naamlik om verskille en verskeidenheid hoog te ag. Indien die klem egter te sterk op die reg van keuse val, sal die unieke betekenis van homoseksualiteit as oriëntasie ondermyn word. 'n Homoseksuele keuse word op dieselfde vlak gestel as ander meer onbeduidende voorkeure byvoorbeeld langer of korter, blonde of donker seksmaats. Sodanige 'swak' evaluering van die homoseksuele lewenstyl veroorsaak dat seksuele oriëntasie ook 'n onbeduidende faktor in die seksuele lewe word (Taylor, 1991:37-38).

Hierdie kritiek kan veralgemeen word as tiperend van die hele Amerikaanse debat oor perversiteit - 'n debat waarin seksuele afwykings soveel moontlik weggeredeneer word. Die morele verontwaardiging wat met die gebruik van die term perversiteit gepaard gaan, en die skerp negatiewe waardelading daarvan, word teengewerk (vergelyk byvoorbeeld Slote, 1975:265; Goldman, 1980:136; Nagel, 1980:88; Gray, 1980:168). Hierdie neiging om die aard van seksuele relasies as onbeduidend af te maak, bring mee dat norme vir seksuele relasies of oriëntasies al minder klem kry. Die gewilde manier om die saak te verduidelik is om te sê dat die unieke aard van seksualiteit as sodanig geen morele implikasie inhou nie 
(Goldman, 1980:130). Reken hierby die algemeen modernistiese neiging tot morele relatiwisme (Bernstein, 1983:13), en 'n bewustheid van die betekenis en belangrikheid van relasie in die uitlewing van seksualiteit verdwyn uit die verstaanshorison van die selfskeppende moderne mens.

\subsubsection{Fokus op die intramenslike aspek van seksualiteit}

Teenoor die relativering van die intermenslike dimensie is die neiging om primêr op die intramenslike dimensie van seksualiteit te fokus. Hierdie neiging kan gesien word in die tendens om ' $n$ enkele intramenslike seksuele funksie in ' $n$ geïsoleerde verabsoluteerde posisie te plaas.

Leiser (1985:343) stel hierdie tendens effektief aan die kaak. Hy argumenteer teen die ouere neiging om ' $n$ enkele interpersoonlike ideaal vir seksualiteit te stel en alle seksuele praktyke wat hiervan afwyk as onnatuurlik te etiketteer. Hy verwerp naamlik die konserwatistiese argument dat die seksuele funksie primêr op voortplanting ingestel is. Alhoewel die seksuele organe op ' $n$ unieke wyse vir voortplanting aangepas is, is dit heel duidelik nie die enigste funksie wat deur seksualiteit gedien kan word nie. Leiser se argument kan nie geld as 'n totale afwysing van die idee dat seksualiteit bepaalde funksies behoort te vervul nie - dit is bloot ' $n$ ontkenning dat seksualiteit ' $n$ enkele primêre funksie besit. Leiser se standpunt is met ander woorde ' $n$ tydige waarskuwing dat die identiteit van seksualiteit nie tot net een funksie beperk kan word nie. Onlangse standpunte oor seksuele normaliteit begaan egter juis hierdie fout. Die algemene tendens in die huidige debat is om (soos Leiser) standpunt teen die identifisering van 'n enkele intermenslike doel vir seksualiteit in te neem, maar om ' $n$ intramenslike funksie tog wel verskuild te bly handhaaf.

Die argument van Goldman (1980:120-121) is 'n duidelike voorbeeld hiervan. Hy kritiseer ' $n$ middel-(afsonderlike)-doel analise van seksualiteit. Sy beswaar is dat mense 'n 'eksteme doel', soos liefde, aan seks koppel asof dit die inherente doel sou wees. Sy eie hipotese van plain sex as die normale uiting van seksualiteit hou in dat die inherente doel van seksualiteit geleë is in die fisiese kontak self en die plesier wat daaruit verkry kan word, eerder as in ' $n$ ander funksie wat die kontak mag vermag. Plesier is hiervolgens inherent deel van die liggaamlike sy van seksualiteit. As voorbeeld van sy kritiek is sy afwys van die ekspressie van liefde as die doel vir seks, belangrik. Volgens hom is dit so dat daar ook ander tipes liefde is as net dié wat seksueel uitgedruk kan word. Hy argumenteer ook dat seksuele aktiwiteit baie ander emosies as net liefde kan uitdruk. Seks kan selfs 'niks' uitdruk nie en steeds, wat hy noem, good sex wees. Goldman se alternatief is egter duidelik ook ' $n$ middel-(seks)-doel-(plesier)-model. Analoog met sy eie argument teen liefde as doel vir seksualiteit, kan gesê word dat plesier ook gevind word op baie ander maniere as bloot net seksuele aktiwiteit. Dit is selfs moontlik 
om 'n aktiwiteit as seksueel te beskryf sonder dat dit noodwendig plesier as hoofdoel hoef te hê. 'n Fyner onderskeiding dui daarop dat plesier eerder 'n emosionele funksie as ' $n$ blote fisiese funksie is. Goldman troetel 'n kontradiksie waarin hy homself skuldig maak aan presies dit waarteen hy hom verset in die standpunt van andere. Goldman is nie sensitief vir hierdie teenstrydigheid nie omdat hy vasgevang is in die eensydige fokus op die intramenslik seksuele funksie 'plesier'. Hyself stel die verabsolutering van plesier amper in soveel woorde:

Whereas Aristotle and Butler were correct in holding that pleasure is normally a byproduct rather than a goal of purposeful action, in the case of sex this is not so clear. The desire for another's body is, principally among other things, the desire for the pleasure that physical contact brings (Goldman, 1980:120).

\section{Oor onderskeidinge en geskeidenhede}

Die argument tot hier was primêr daarop ingestel om die skeiding tussen die interen intradimensies van seksualiteit aan te toon. Hierdie waarneming sal vervolgens ' $n$ stap verder geneem word deur aan te toon dat so 'n skeiding 'n onvolledige en verwronge beeld van seksualiteit daarstel.

\subsection{Dialektiek van die interpersoonlike relatiwisme}

Een van die sterkste argumente uit die relatiwistiese hoek is dat daar geen praktyk is wat universeel deur alle mense en kulture aanvaar word nie. Die empiriese teenargument, aan die ander kant, is dat daar bitter min mense of kulture is wat nie een of ander praktyk as paradigmaties beskou en selfs sekere taboes op grond daarvan neerlê nie (Kosnik, 1977:60). Dit lyk asof 'n dialektiek van relatiwisme nie ontsnap kan word nie. Konsekwente relatiwisme is 'n onhoudbare standpunt; indien aan sy eie maatstaf beoordeel, naamlik dat geen universele waarhede of wetmatighede moontlik is nie, sal die waarheidaanspraak dat alle waarheid of wetmatigheid relatief is, verkrummel

Die uitskuif van die intermenslike faset van seksualiteit uit die sfeer van algemeen aanvaarde seksuele norme word inderdaad nie oral sonder slag of stoot aanvaar nie. Kadish $(1987: 34-37,46)$ wat meen dat hy universele gronde kan aandui waarop praktyke as pervers beoordeel kan word, bevraagteken die aanspraak dat seksualiteit ' $n$ primêr private (nie-intermenslike) aangeleentheid is. Die bestaan en regverdiging van seksuele norme vind hy in die mens se sosiale natuur en wel in die feit dat die mens se identiteit deur die gemeenskap en sy belange bepaal word. Met hierdie begronding meen hy dat seksuele gedrag wat die diepere struktuur van die gemeenskap bedreig, wel as afwykend veroordeel kan word. Afwykende seksuele gedrag hou 'n bedreiging in vir die gesin en geslagtelike orde soortgelyk aan die bedreiging van anargisme vir die totale sosiale orde. Hierdie 
standpunt handhaaf wel 'n mate van relatiwisme: indien die belange van die sosiale orde verander, sal dit wat as pervers gesien word, ook verander. Hierdie is egter ' $n$ 'sagter' of minder radikale vorm van relatiwisme in die sin dat veronderstel word dat binne ' $n$ bepaalde tydvak daar wel 'n dieper sosiale struktuur is wat as toetssteen vir die pluraliteit van standpunte op die oppervlakte dien (Kadish, 1987:45-47). Kadish se poging is dus minstens 'n bevestiging van die standpunt dat 'n radikale relatiwisme van interpersoonlike seksuele norme nie enduit konsekwent is nie.

\subsection{Seksuele natuur versus gekultiveerde seksualiteit}

Die dialektiek van relatiwisme met sy besef dat die aard van seksualiteit nie volledig relatief tot ' $n$ bepaalde subjektiewe standpunt beskryf kan word nie, vind egter dieper inslag as wat besef word. Heelwaarskynlik as gevolg van hierdie dialektiek, word voorsiening gemaak vir 'n universele struktuur vir seksualiteit, ten minste in wat genoem word die natuur van die mens. Die dialektiek van die relatiwisme lê dus ten diepste in die verlengde van 'n kultuur-natuurspanning.

Hierdie standpunt kan afgelees word in onder andere die nominalistiese standpunt van Leiser (1985:340-341) wat reken dat die natuurlikheid van seksualiteit dui op die ooreenstemming daarvan met die deskriptiewe wette van die natuur. Volgens Leiser beskryf hierdie wette bloot die manier waarop fisiese entiteite hul gedra. Hierdie wette is nie voorskriftelik ten opsigte van gedrag soos ' $n$ wet in die juridiese sin dit doen nie. Daarom maak dit nie sin om te sê dat 'n natururwet oortree word in seksuele perversiteite nie - as daar ' $n$ werklike uitsondering van sodanige natuurwette is, is dit bloot nodig om die wet te herskryf en die eerste wet verval asof dit geen wet sou gewees het nie. Leiser is met ander woorde daarvan oortuig dat seksualiteit behoort tot 'n natuurlike orde wat 'n meganika van sy eie het en onafhanklik van menslike singewing funksioneer.

'n Tweede manier om dieselfde metafisika te stel is om seksuele norme as blote subjektiewe oordele te sien wat op ' $n$ inherente neutrale natuur geprojekteer word. So byvoorbeeld argumenteer Slote (1975:261-262) dat dit onmoontlik is om aan te dui wat die kriteria vir natuurlik en onnatuurlik in die seksuele sfeer is. Onnatuurlike seksualiteit is nie ' $n$ blote aanduiding van immoraliteit nie aangesien sake soos owerspel en ontug ook as verkeerd beskou word maar dit word nie as pervers getipeer nie. Slote lei hieruit af dat die bedoeling van die tipering onnatuurlik daarop dui dat so 'n aktiwiteit buite die natuur en buite ons wêreld is. Volgens hom is sodanige aanspraak onsinnig. Hiermee identifiseer hy alle seksualiteit met 'n intra-individuele drang of instink wat onafhanklik en selfs teenoor interpersoonlike norme (wat vir hom volledig kultuurrelatief is) funksioneer. Hierdie streng skeiding tussen die natuurlike gegewe en die menslike kultivering daarvan 
is verdag. Selfs diere, wat veronderstel is om suiwer 'natuur' te wees, besit die vermoë om soms onnatuurlik op te tree ${ }^{3}$.

Die intra-individuele dimensie van seksualiteit kan dus nie voorgehou word as ' $n$ natuurlike gegewe wat nie inherent beïnvloed en gevorm kan word deur die kultivering daarvan nie. Die huidige skeiding tussen natuur en kultuur is die gevolg van ' $n$ verabsolutering van die seksuele instink of, alternatiewelik, word veroorsaak deur die totale redusering van seksualiteit tot die intramenslike dimensie van seksualiteit.

\subsection{Skeidinglose onderskeiding}

Leiser en Slote forseer ' $n$ blote teoretiese onderskeid te ver. Albei veronderstel dat wette in die natuurlike sin net ' $n$ soort passiewe beskrywing is van hoe sake buite die wil van die menslike subjek om gesteld is. Daarteenoor veronderstel wette in die juridiese of sosiale sin 'n volledig skeppende menslike agent. Tog bly die sogenaamde deskriptiewe wette steeds beskrewe natuurwette en is dus tot 'n hoë mate die breinkind van 'n menslike agent. Aan die ander kant is dit ook duidelik dat geen juridiese wetgewer durend-geldige wette kan formuleer wat byvoorbeeld geregtigheid as strukturele gegewenheid negeer nie. Ook die juridiese wetgewer probeer iets onder woorde bring wat onafhanklik van die skeppende aksie van ' $n$ menslike agent om realisering roep. Die onderskeid tussen die situasie van 'n sogenaamde natuurding en die menslike situasie is nie geleë in die aanwesigheid van ' $n$ strukturele wetmatigheid in die eerste situasie en 'n afwesigheid daarvan in die menslike situasie nie. Deskripsie en preskripsie, menslike natuur en die kultivering daarvan, is abstraheringe en kan in konkrete formuleringe (soos in die formulering van natuur- en juridiese wette) nie absoluut van mekaar geskei word nie. Dit is wel waar dat daar 'n verskil gesien kan word in die situasie waar ' $n$ mens aan ' $n$ wet onderworpe is en waar ' $n$ sogenaamde natuurding wette moet gehoorsaam. Laasgenoemde het ' $n$ mindere vermoë om ' $n$ vrye keuse uit te oefen en verantwoordelikheid vir daardie keuse te aanvaar as ' $n$ mens. Indien ' $n$ natuurwetenskaplike enkele gevalle identifiseer waar gravitasiekrag byvoorbeeld oortree word, sal hy gedwing wees om ' $n$ nuwe formulering aan die gravitasiewet te gee. Die mens aan die ander kant kan die norme wat vir hom

3 In dié verband wys Margolis (1975:302) op 'n insiggewende stukkie kritiek op die standpunt van Slote:

The curious thing is that, contrary to widespread belief, homosexuality is almost unknown in the animal world - appearing only under conditions of extreme stress, never consummated in intercourse, and regularly confused with aggressive play ... Deviation is possible in nature, so the 'unnatural' occurs in nature. This goes against an argument by Michael Slote ...". 
geld, oortree sonder dat dit 'n genoegsame rede is om die wet anders te formuleer of sonder meer op te skort. Die saak is egter nie so verskillend dat ' $n$ analogie nie moontlik is nie. Indien daar byvoorbeeld ' $n$ hoë insidensie van die oortreding van 'n munisipale ordinansie is, sal die wetgewers wys wees om weer na die wet te kyk - die wet kan moontlik skry teen dit wat regverdig is.

Vir seksualiteit is die konsekwensie duidelik: daar is sekere etiese en sosiale gegewenhede wat geslagtelike handeling tussen mense reël. Hierdie intermenslike strukture is nie so dwingend in hul gelding as gravitasiekrag nie; daarom is dit so dat daar omtrent nie 'n seksuele praktyk is wat in een gemeenskap as 'n perversiteit en in 'n volgende as normaal gesien word nie. Dit is egter nie genoegsame rede om te veronderstel dat normaliteit nie bestaan nie. Immers, die vergelykbare begrip geregtigheid kan in sy betekenis van gemeenskap tot gemeenskap verskil, maar dit beteken nie dat die mensdom as geheel hande in die lug gooi en aanvaar dat geregtigheid nie bestaan nie. Intermenslike seksuele strukture bestaan wel onafhanklik van die formulering daarvan deur die gemeenskap. Hierdie nivellering van die grens tussen kultuur en natuur geld ook na die ander kant; die intra-individuele sy van seksualiteit kan nie totaal uitgelewer word aan 'n determinerende natuurkrag nie. Net soos wat natuurwetenskaplikes verantwoordelik gehou word vir die korrektheid van hul weergawe van die wetmatighede wat geldig is vir natuurlike fenomene asook die toepassing van hul kennis, so kan ' $n$ individu verantwoordelik gehou word vir die vormgewing wat hy aan sy inherente seksuele vermoëns en kenmerke gee. Dit beteken dat nie gesê kan word dat struktuur wel bestaan in die intramenslike faset van seksualiteit maar nie in die intermenslike faset nie. 'n Absolute skeiding tussen die menslike vormgewing van dit wat seksueel normaal tussen mense is en dit wat ' $n$ seksueel gegewe binne mense is, kan dus nie op grond van die bestaan en niebestaan van strukturaliteit binne die twee dimensies gemaak word nie.

\subsection{Identifiserende normering en normerende identifisering van seksualiteit}

Die meeste definisies van normale seksualiteit toon 'n onvermoë om sowel die inter- as die en intramenslike dimensies sinvol tot 'n gegewe maar tegelyk menslik gevormde struktuur te integreer. Daar word meestal gekonsentreer op die intramenslike sy van seksualiteit vir die sogenaamde neutrale identifisering of beskrywing van die struktuur van seksualiteit met die voorbehoud dat hierdie identifisering geen gevolg mag hê vir 'n seksuele etiek nie. Die moraal op sy beurt, so word veronderstel, mag geen invloed hê op die identifisering van seksualiteit nie. Die moderne strategie is om rigiede grense te konstrueer waarvolgens veronderstel word dat die wat van seksualiteit in die intramenslike sy en die hoe in die intermenslike sy van seksualiteit geleë is. Die poging om die intramenslike aspek te verhef tot die enkele identifiserende aspek van seksualiteit lei daartoe dat die 
meer intermenslike fasette van seksualiteit uit die identifisering van seksualiteit gerangeer word en dit 'n mindere subjektiewe funksie kry.

Dit is egter 'n onhoudbare posisie: sowel die inter- as die intramenslike aspekte het ' $n$ identifiserende én preskriptiewe funksie ten opsigte van seksualiteit. Die beskrywing van en ideaalstelling vir seks kan nie onderverdeel word tussen die verskillende aspekte van seks nie. Dit is nie moontlik om te redeneer asof sekere funksies (gewoonlik intramenslike funksies soos die genotsgevoel) seks buite die menslike wil om determineer terwyl die menslike beoordeling en waardering van normale seks (preskripsie) in ander funksies (gewoonlik die etiese) gesetel is nie. Moulton (1980:117) wys tereg daarop dat die karakterisering of identifisering van die uniekheid in seksualiteit 'n paradigma daarstel. Hierdie paradigma het op sy beurt duidelike morele implikasies - dit geld mutatis mutandis ook vir die etiese funksie. Norme wat reg en verkeerd in seksuele verhoudings voorskryf, is nie net 'n aangeplakte waardekomponent tot die eintlike identiteit van seksualiteit nie. Die erotiese aard van seksualiteit is inherent deel van die definiëring van seksualiteit.

Die redusering van die struktuur vir seksualiteit tot net een sy daarvan het die konsekwensie dat sowel die identifisering as die normering van seksualiteit inkonsekwent en selfs onmoontlik word. 'n Sprekende voorbeeld hiervan is Gray (1980:162) se toepassing van die plesierdogma. Gray stel hom ook teen 'n standpunt wat die doel van seksualiteit in ' $n$ intermenslike funksie soek. Hy vra egter wel wat die wesenselement is van dit wat van 'n seksdaad 'n seksdaad maak. In beantwoording van sy eie vraag beklemtoon ook hy die intramenslike plesierfunksie asof dit van seksualiteit seksualiteit maak. Gray gebruik die voorbeeld van 'n verkragtingslagoffer om sy standpunt te illustreer. Volgens wat hy 'n (onvoldoende) coïtusmodel vir seks noem, is die slagoffer van verkragting wel betrokke by 'n seksdaad. Gray verwerp so 'n aanspraak en meen dat sy plesiermodel die oplossing bied: die slagoffer het geen genot aan die daad nie, dus is dit nie seks nie. Dit is egter belangrik om op te merk dat Gray hiermee nie net 'n blote beskrywing van seks gee nie. Ruddick $(1975: 84,93-95,101)$ is nader aan die kol as sy stel dat die plesierkomponent seksualiteit reeds waardegelade en dus moreel beoordeelbaar maak. Sy stel onder andere voor dat 'n meerdere mate van plesier sekere seksuele dade onderskei as beter as ander. Daarom glo sy dat plesier 'n primae facie morele waarde dra. Dié implikasie het verreikende gevolge vir Gray se standpunt. Hoewel verkragting vanuit die oogpunt van die slagoffer geen seks is nie, is dit volgens die plesiermodel nie noodwendig die geval met die verkragter self nie: die verkragter se daad kan volgens Gray se model as seks en selfs as normaal beskryf word omdat dit vir die verkragter tot plesier lei. Daar is egter min mense wat die handeling van 'n verkragter as normaal sal beskryf. Die identifisering van 'n enkele funksie as strukturele identiteit vir seksualiteit lei tot 'n 
ontoereikende preskripsie vir normale seksualiteit. Meerdere interpersoonlike funksies moet minstens bygevoeg word om die prentjie te voltooi.

Dit is egter nie net die definisies wat fokus op die intramenslike fasette van seksualiteit wat ontoereikend is nie. Ten diepste gee 'n kritikus van die hedonistiese dogna, Solomon, dieselfde soort verengde definiëring aan seksualiteit vanuit die interpersoonlike pool. Solomon spreek homself sterk uit teen die idee dat seksualiteit ' $n$ eksklusiewe genotsdoel beoog - plesier vergesel volgens hom bloot die aktiwiteit en aktiwiteitsdoelwitte, maar plesier is nie die aktiwiteit self of selfs die doelwit van die aktiwiteit nie. Laasgenoemde primêre funksie vir seksualiteit sien hy in kommunikasie - seksualiteit is lyftaal wat bepaalde semantiese inhoude oordra. Perversiteite word dan slegs as ' $\mathbf{n}$ afwyking van die kommunikasiefunksie van seksualiteit gesien (Solomon, 1974:341-345). Weer eens is dit ' $n$ vraag of seksualiteit primêr gesien kan word as net 'n kommunikatiewe handeling of alternatiewelik, kan alle kommunikasie as seks beskryf word? Om die waarheid te sê, die meeste konserwatiewe aanduidings wat die sogenaamde doel van seksualiteit primêr in óf reproduksie of liefde sien, is dit eens met die reduksionistiese greep van die meer vrysinnig hedonistiese definisies vir seksualiteit. Daarom kan nie een van die voorgestelde identifiserende funksies van seksualiteit - plesier, liefde, prokreasie of kommunikasie - in isolasie die identiteit en normering van ' $n$ seksdaad bepaal nie. ${ }^{4}$

\section{Normale / abnormale seksualiteit}

Uit die voorafgaande analise van die tendense in die diskoers oor seksualiteit en die onderliggende eensydighede van hierdie diskoers kan nou enkele afleidings omtrent normale seksualiteit gemaak word:

4 Vergelyk in dié verband die insig van Zijlstra (1971:53) omtrent die geslagtelike onderskcid:

\footnotetext{
I became sufficiently disappointed with the direction these studies gencrally took to ask mysclf whether there was nothing more to sexuality than a rather vague kind of emotional love relationship superimposed on a biotic structure whose relevancy in this case is specifically reduced to the so called primary and secondary sexual organs. I came to the tentative conclusion that the common problematic usually arose out of a wrong ontology which accentuated a rcal difference (biotic and non-biotic aspects) to a discrepancy, which in turn needed to be disguised by asserting the necessary presence of such functions as trust, tenderness, sensitivity in order to realize the sexual (biotic) interpersonal relations. In contrast to this approach, I maintained that sexual difference could not be located in onc or two aspects and that sexual expression could not be qualified by any human aspect, but that both were to be related to the whole individuality structure.
} 
Eros en seksuele natuur

Seksualiteit bestaan uit twee dimensies. Die eerste dimensie word veral gemanifesteer in die verhouding waartoe die mens tot sy eie aangebore liggaamlike geslagtelikheid en biotiese en emosionele drange staan. Dit kan die intramenslike faset van seksualiteit genoem word. Kainz (1981:45) gee 'n nadere omskrywing van hierdie funksionering van liggaamlike geslagtelikheid:

\begin{abstract}
At this point it might be best to return to the bisexuality of the human fetus, and take this as a kind of symbol and watchword for our further investigation of $\mathrm{M}-\mathrm{F}$ differentiation. It is perhaps natural for us to want to classify but, in a very real sense, there are no men and no women per se, except on the merely physical level of M-F sex organs, glands, and chromosomal makeup. When we move to the levels of physique, physiology, temperament, personality, behavior and 'metaphysical' characteristics (if there be any such), there are only M-F predominances, which have a way of distributing themselves in infinitely variable and unpredictable ways.
\end{abstract}

Hy suggereer die vastheid van 'n sekere primêre geslagtelikheid wat nie anders kan as om verder kultureel en sosiaal ontsluit te word nie. Wanneer gevra word hoe hierdie ontsluiting plaasvind, kom die tweede dimensie van seksualiteit ter sprake. Vanuit die argument dat die erotiese dimensie integraal deel is van seksualiteit, blyk dit dat ontsluiting veral in die seksuele verhoudings tussen mense voltrek word. Anders gestel: deur middel van erotiese begeertes en handelinge waarin verbinding tussen mense tot vergestalting kom, ontwikkel die geslagtelike en instinktiewe potensiaal tot ' $n$ volle dimensie van menswees. Hierdie ontplooiing van geslagtelikheid staan onder leiding van 'n hele aantal funksies wat almal ' $n$ intermenslike dimensie met mekaar in gemeen het. In hierdie visie op die ontplooiing van geslagtelikheid is dit duidelik dat daar geen sprake kan wees van ' $n$ innerlike seksuele drang as vergestalting van 'n natuurmag binne die mens wat sigself onafhanklik of selfs teenoor en in weerstand tot die erotiese vormgewing daarvan stel nie. Die vormgewing aan seksualiteit veronderstel immers 'n seksuele potensiaal en andersom.

Daar kan dus twee argumente teen die huidige diskoers oor seksualiteit geïdentifiseer word:

* $\quad$ 'n Argument teen die skeiding van die twee dimensies van seksualiteit.

* In samehang met eersgenoemde die argument teen die volslae relativering van 'n struktuur vir intermenslike seksualiteit aan die een kant en 'n afwys van die verabsolutering van die noodwendigheid van die intramenslike struktuur vir seksualiteit aan die ander kant.

Hierdie twee argumente, meen ek, kan ons lei tot die identifisering van seksuele abnormaliteite as praktyke waarbinne veral die intermenslike struktuur van sek- 
sualiteit onderdruk of wanontplooi word. Dit beteken in die meeste gevalle dat seksuele potensiaal gesien word as ' $n$ stuk natuur geisoleer van die etiese handelinge en verantwoordelikhede van ' $n$ intermenslike relasie.

So byvoorbeeld is ' $n$ seksfobie, soos vergestalt in 'n onderdrukking van erotisiteit (onder andere in die Victoriaanse moraal gepoog), die ontkenning van die noodsaak dat die intramenslike faset van seksualiteit om sinvolle volledige ontsluiting vra. Heelwaarskynlik is sekere neurotiese verskynsels die uitvloeisels van hierdie wilsinperking van die mens se geslagtelike potensiaal. Op dieselfde wyse is seksualisme ' $n$ beheptheid met die intramenslike drang - tot so ' $n$ mate dat die persoon van die ander mens op wie die seksuele beweging gerig behoort te word, grootliks tot die agtergrond vervaag (bv. nimfomanie, seksverslawing en selfs ' $n$ radikaal promiskue lewenstyl). In hierdie opsig word die uitlewing van die intramenslike faset van seksualiteit gesien as ' $n$ drang wat nie verder ontsluit hoef te word deur gepaste erotiese of intermenslike funksies nie.

Perversiteite op hul beurt is die koester en uitleef van erotiese begeertes ten opsigte van nietoepaslike objekte - dit wil sê objekte wat nie die intermenslike aard van seksualiteit respekteer nie (bv. bestialiteit, fetisjisme ens.). Perversiteite kom egter ook na vore in die uitleef van erotiese begeertes wat werklike menslike verhoudings nie waardig is nie; byvoorbeeld sadisme en masochisme asook verkragting. Hiermee word seksualisme tot 'n uiterste gevoer deurdat die intermenslike funksies van seksualiteit totaal geignoreer word.

Laastens, indien die seksuele aanleg van die mens intermenslik verkeerd gerig word, gebeur dit dat geslagtelikheid hom laat geld in ontoepaslike menslike relasies. So byvoorbeeld word geslagtelikheid baie keer deur die vrou ervaar as die basis vir allerlei diskriminerende praktyke. Ferguson (1980:235) se feministiese kritiek op die idee dat man en vrou nie afsonderlik kan bestaan nie, dat hulle mekaar benodig vir feitlik elke aspek van menslike funksionering, is dus geldig. Hierdie idee veronderstel dat die mens geslagtelike instinkte het wat so sterk is dat dit alle kulturele en sosio-ekonomiese gedrag determineer. Hierteenoor argumenteer sy dat geslagtelike gedrag eerder aangeleer as instinkmatig gedetermineer word. Indien seksuele kenmerke dus tot diskriminasie op terreine soos die arbeidsmark lei, word die invloed van die intramenslike dimensie van seksualiteit te ver gevoer. Dit behoort inderdaad ' $n$ afwyking geag te word indien geslagtelikheid ' $n$ invloed het in verhoudings waar dit nie van toepassing behoort te wees nie. Indien iemand se lot op die arbeidsterrein, godsdienstige terrein en selfs in die gesinsopset totaal bepaal word op grond van sy/haar geslagtelikheid, is dit niks anders as seksisme, dit wil sê 'n oorbeklemtoning van geslagtelikheid in minder geslagtelik relevante handelinge en menseverhoudings nie. 


\section{Slot}

Samevattend die volgende oorsig oor die verloop van die argument: Die sentrale vraagstuk wat ondersoek is, was om kriteria te vind vir die identifisering van normale seksualiteit in onderskeid van abnormale seksualiteit. Die voorwaarde vir 'n antwoord op hierdie vraag is dat daar duidelikheid sal wees oor die plek en aard van seksualiteit in die mens se lewe.

In die verkenning van hierdie plek van seksualiteit in die mens se lewe is daarop gewys dat ons kultuur gekenmerk word deur 'n dichotomie tussen die inter- en intrapersoonlike dimensies van seksualiteit wat 'n versteurde blik op die aard en plek van seksualiteit gee. Hiermee word bedoel dat die aangebore geslagtelike potensiaal van die mens gesien word as 'n determinerende natuur terwyl enige seksuele etiek gesien word as die gevolg van die vrye outonome beslissing van die mens. Volgens sekere radikale sieninge word seksuele instinkte selfs gesien as die konkrete terwyl 'n seksuele moraal nie veel meer as 'n stuk aangeplakte metafisika is nie. Indien hierdie twee dimensies so gesien word, maak hulle teenoorgestelde aansprake op die seksualiteit van die mens wat nie tot 'n sintese gevoer kan word nie. Daarom word ons kultuur gekenmerk deur 'n verabsolutering van die eise van die sogenaamde seksuele natuur van die mens met 'n gevolglike etiese relativering.

Hierteenoor is geargumenteer vir 'n relativering van die rigiede geskeidenheid tussen seksuele natuur en seksuele moraal. Albei aspekte is nodig vir die volledige identifisering van die unieke aard van seks asook die daarstel van 'n norm vir seksualiteit. Hiermee word 'n model vir seksuele normaliteit duideliker: normale seksualiteit vra vir die gestruktureerde interpersoonlike ontplooiing van die intrapersoonlike seksuele potensiaal. Seksuele abnormaliteite is dan veral 'n ontkenning van die noodsaak van 'n ontplooiing binne die kaders van die interpersoonlike; abnormaliteite word vergestalt in wanstaltige seksuele verhoudings.

\section{Bibliografie}

BERNSTEIN, R.J. 1983. Beyond Objectivism and Relativism: Science, Hermeneutics and Praxis. Oxford : Basil Blackwell

FERGUSON, A. 1980. Androgyny as an Ideal for Human Development. (In Soble, A. ed. The Philosophy of Sex: Contemporary Readings. Totowa, New Jersey : Rowman and Littlefield, pp. 232-255.)

FOUCAULT, M. 1977. Discipline and Punish: the Birth of the Prison. (Transl.: Sheridan, A.) London : Allen Lane.

FOUCAULT, M. 1979. The History of Sexuality, Volume 1. (Transl.: Hurley, R.) London : Allen Lane

GOLDMAN, A. 1980. Plain Sex. (In Soble, A. ed. The Philosophy of Sex: Contemporary Readings. Totowa, New Jersey : Rowman and Littlefield. pp. 119-138.) 
M.F. Heyns

GRAY, R. 1980. Sex and Sexual Perversion. (In Soble, A. ed. The Philosophy of Sex: Contemporary Readings. Totowa, New Jersey : Rowman and Littlefield, pp. 158-168.)

HUMBER, J.M. 1988. Sexual Perversion and Human Nature. Philosophy Research Archives, 13: $331-350$

KADISH, M.R. 1987. The Possibility of Perversion. The Philosophical Forum, 19(1):34-53.

KAINZ, H.P. 1981. The Philosphy of Man: a New Introduction to Some Perennial Issues. Alabama : The University of Alabama Press.

KOSNIK, A. 1977. Human Sexuality: New Directions in Catholic Thought. London : Search Press.

LEISER, B.M. 1985. Homosexuality and the 'Unnaturalness Argument'. (In Velasquez, M. \& Rostankowski, C., eds. Ethics: Theory and Practice. Englewood Cliffs, New Jersey : Prentice-Hall. pp. 339-346.)

MARGOLIS, J. 1975. The Question of Homosexuality. (In Baker, R. \& Elliston, F., eds. Philosophy \& Sex. Buffalo : Prometheus, pp. 288-302.)

MOULTON, J. 1980. Sexual Behavior: Another Position. (In Soble, A., ed. The Philosophy of Sex: Contemporary Readings. Totowa, New Jersey : Rowman and Littlefield, pp. 110-118.)

NAGEL, T. 1980. Sexual Perversion. (In Soble, A., ed. The Philosophy of Sex: Contemporary Readings. Totowa, New Jersey : Rowman and Littlefield. pp. 76-88.)

PLATO. 1931. Symposium, or Banquet. (Transl.: Shelley, P.B.) (In Five dialogues of Plato Bearing on Poetic Inspiration. London: J.M. Dent. pp. 17-71.)

RUDDICK, S.L. 1975. Better Sex. (In Baker, R. \& Elliston, F., eds. Philosophy \& Sex. Buffalo : Prometheus. pp. 83-104.)

SLOTE, M. 1975. Inapplicable Concepts and Sexual Perversion. (In Baker, R. \& Elliston, F., eds. Philosophy \& Sex. Buffalo : Prometheus. pp. 261-267.)

SOLOMON, R.C. 1974. Sexual Paradigms. The Journal of Philosophy, 71(11):336-345.

TAYLOR, C. 1985. Justice after Virtue. (In Benedikt, M. \& Burger, R. Kritische Methode und Zukunft der Anthropologie. Wien : Wilhelm Braumüller. pp. 23-49.)

TAYLOR, C. 1989. Sources of the Self - the Making of the Modern Identity. Cambridge : Cambridge University Press.

TAYLOR, C. 1991. The Malaise of Modernity. Ontario : Anansi.

ZIJLSTRA, D. 1971. Sexology: Preliminary Comments. Correspondentie-bladen van de Vereniging voor Calvinistische Wijsbegeerte, 35: 53-63. 
